\title{
HUMAN RIGHTS INFRINGEMENT AGAINST CONTEMPORARY LEGAL PRACTICE IN SEVERAL CRIMINAL CASES
}

\begin{abstract}
Issues connected with protection against tortures or other forms of inhuman or degrading treatment are regulated in the European law not only in The Convention for the Protection of Human Rights and Fundamental Freedoms, but also in The Convention against Torture and Other Cruel, Inhuman or Degrading Treatment or Punishment, which was adopted by The Committee of Ministers of the Council of Europe on June 26, 1987 and later ratified by all 47 countries of The Council of Europe. It is a key element in amending the control system. It has been agreed that the system based on individual and international pleas should be supported by preventive measures. Various situations in which the state has serious obligations so as to protect art. 3 of the Convention, take place following criminal proceedings by organs entitled to act according to legislation. It ought to be mentioned that despite our country's ratification of the above mentioned legal acts, while conducting pre-trial proceedings in criminal cases, the violation of basic human rights and inhumane treatment of the suspects or the accused happen the most often. The state is responsible for securing proper conditions that would grant respect for one's dignity and the procedures and methods of obtaining incriminating evidence are not to cause suffering whose scale and intensity would surpass needs of personal security of the accused or suspects during the proceedings in criminal trials, with respect to the legal procedures regulating the arrest and the use of preventative measures in form of a detention order.

Keywords: human rights, protection of human rights and fundamental freedoms, prohibition to use tortures and inhuman treatment, pre-trial detention, incriminating evidence, right to defense, complain to the European Court of Human Rights.
\end{abstract}

\section{INTRODUCTION}

The integration of Poland with European Union in the business and economical aspects, inextricably linked with an immediate adjustment to EU legal system, aimed at offering increased guarantee of respecting the existing law and freedom by the government to the public.

The crucial issue for each and every citizen was respecting basic human rights, given to all human beings and standing for a man's dignity, by the authorities. To raise its importance, state authorities decided to sign numerous international

* Uniwersytet Łódzki, Wydział Prawa i Administracji, Katedra Postępowania Karnego i Kryminalistyki UŁ, katerydz@wp.pl 
agreements as a guarantee of its indisputable presence in the state's legal framework. The fundamental act that the Republic of Poland applied was undoubtedly The Convention for the Protection of Human Rights and Fundamental Freedoms ${ }^{1}$. Apart from the basic right to live, the right to being treated in a dignified and humanitarian way, which is realised in the prohibition to use tortures, was of upmost importance. Article three of the abovementioned Convention mentions such prohibition. Due to it, nobody can be tortured or undergo inhuman or degrading treatment or punishment.

The issues connected with the protection against tortures of other forms of inhuman or degrading treatment are regulated in the European law not only in The Convention for the Protection of Human Rights and Fundamental Freedom, but also in The Convention against Torture and Other Cruel, Inhuman or Degrading Treatment or Punishment, which was adopted by The Committee of Ministers of the Council of Europe on June 261987 and later ratified by all 47 countries of The Council of Europe ${ }^{2}$.

It is a key element in amending the control system. It has been agreed that the system based on individual and international pleas should be supported by preventive measures (Nowicki 2013).

That is why The European Committee for the Prevention of Torture and Inhuman or Degrading Treatment or Punishment was established (CPT), which was meant to be independent and entitled to visit all detention locations was established.

Its role is to prevent the inhumane acts against detainees. The Convention states that the Committee works not only during peace, but also, with minor restrictions, during war and states of emergency. On March 1, 2002, two Protocols came to force. Protocol $1^{3}$ to The Convention against Torture and Other Cruel, Inhuman or Degrading Treatment or Punishment, granting to The Committee of Ministers of the Council of Europe the right to ask any non-membership country to join the organization, and Protocol $2^{4}$, regulating the technical issues connected with the organization of CPT.

\section{LEGAL INSTRUMENTS GRANTED BY THE POLISH CRIMINAL PROCEDURAL CODE}

Various situations in which the state has serious obligations so as to protect Art. 3 of the Convention, take place following criminal proceedings by organs entitled to act according to legislature. It ought to be mentioned that despite our

${ }^{1}$ The Convention for the Protection of Human Rights and Fundamental Freedoms drafted in Rome on November 4, 1950, then amended by Protocols 3, 5 and 8 and advanced by Protocol 2 (Dz. U. of June 10 ${ }^{\text {th }}, 1993$, No 90, p. 587).

${ }^{2}$ Came into force on February 1, 1989.

${ }^{3}$ Protocol No 1 and No 4 (Dz. U. 1995, No 36, p. 175/1 - binding act).

${ }^{4}$ Protocol No 2 (Dz. U. 1995, No 36, p. 176 - archival act). 
country's ratification of the abovementioned legal acts, while conducting pre-trial proceedings in criminal cases, the violation of basic human rights and inhumane treatment of the suspects or the accused happen the most often.

The state is responsible for securing proper conditions that would grant respect for one's dignity and the procedures and methods of obtaining incriminating evidence are not to cause suffering the scale and intensity of which would surpass the needs of personal security of the accused or the suspects during the proceedings in criminal trials, with respect to the legal procedures regulating the arrest and the use of using preventative measures in form of a detention order. The state is entitled to use practical means to effectively protect detainees against the dangers connected with the process practice of the pre-trial organs and special procedures of revealing losses and mistakes that may happen due to the acting of people on diverse levels of the decision-making organs, responsible for conducting the proceedings. The dangers may be connected with, for instance, with the enforcement of incriminating testimony or explanations, providing de facto evidence against oneself, which is contradictory to the key principle of the process expressed in the Polish Code of Criminal Procedure.

The prohibition of the use of tortures or inhumane treatment equals, therefore, the prohibition of physical violence or threats, a need of protection of health and the well-being of the person in custody, the suspect, and finally the accused, for instance by providing, if necessary, the required medical care, medication distribution, dressing change and the possibility to satisfy the very basic physiological needs 5 .

\section{CURRENT SITUATION IN POLAND}

The abovementioned risks are not purely theoretical examples, unfortunately, but they occur in ongoing criminal cases, especially at the stage of prosecution. Despite the fact that Poland is a country that wishes to be proud of compliance with the principles of law, it still struggles with the basic problems arising from the lack of respect for human dignity of detainees. Moving on to discuss practical examples -the violation of obvious fundamental principles of respect for human health, which ceases to be valid in the face of the purpose of investigation, should be mentioned. In numerous cases $^{6}$, taking and carrying out procedural actions despite a very poor state of health of the person involved is a fact.

${ }^{5}$ Sentence in the case Chember Against Russia from July 3, 2008, Chamber (Section I), application No. 7188/03, § 50; An action against Turkey No. 40145/98 - sentence from 2005; Complaint v. Spain No. 51192/99 - decision of 2001.

6 Three examples presented as: example number I, number II and number III. First has been conducted before the district Court - City Centre in Lodz in 2009-2013, the second one - has been conducted before the district Court in Pabianice City in 2007-2010, finally the third one 


\subsection{Case number I}

Many a time there comes the issue of prosecution decisions resulting in arrest, and so in the present case (example number I), the defendant in the second day after leaving the hospital after invasive oncological surgery. The officers executing the detention procedure did not even inform the accused about the fact that it was an act of detaining him; they seemed disinterested in the sick leave the accused possessed or very serious condition of his health. The accused was instructed only to take warm clothing, but even then he was not informed about the need to escort him to another city located about three hundred kilometers from the place of his residence for prosecutorial interrogation. Leaving the apartment he was convinced that he would be transported to the police station, where he would only make a statement or give explanation. He was not given any details about the nature of his arrest (whether he was a witness or the suspect). Submitting his serious health problems, he was told that he would be examined by a doctor before procedural actions at the police station. None of these activities with the participation of the accused was performed (as evidenced by the lack of protocols of these actions in the files of the investigation), which led to a clear violation of his procedural rights, including the basic principles of humanity. The accused demanded a medical examination at the place of his residence, but was informed that such a study would be carried out at the place of their inquiries after about five hours of the journey. Of course, the request of the then suspect is not mentioned in the file, since it is known that such a record would impose a need of explanation from the organs responsible for the process in front of the court of why the activities against the suspect were carried out without a medical examination and against his will. After the transfer to the Public Prosecution Office, the question of the accused - when he would be released - received a reply from the person conducting the hearing that this would depend on the content of submitted explanations in the case. The form of study in the Custody Suite - which is in fact a sham - confirmed only that all vested rights of the suspect - were openly omitted or ignored by the representative of the Prosecutor s' Office investigating. For a person arrested for the first time in his life, having no legal training or knowledge of the powers of the authority conducting the investigation, but having a great medical knowledge and understanding about his condition, the method of treatment in isolation as well as the awareness of ongoing activities with his participation - a decision to make incriminating explanation was clear enough from the point of view of the application of physical force and inhuman treatment. Apart from that, during the next hearing day, the Prosecutor executing action was also not interested in the health of the accused. Thus, signing of the protocols drawn from the suspect

- has been conducted before the district Court in Zgierz City in 2007-2009. All cases have been finally completed. In the first case, defendant has been sentenced as innocent. 
hearing was due to an obvious psychological compulsion. Inhumane treatment, humiliation, placing him in an offensive situation, exposure to the deterioration of health, including threatening his life (dehydration in Custody Suite), and finally the obvious suggestion of person conducting the questioning that the decision to discontinue the use of detention depends on the submission of incriminating explanations - all this together indicate a violation of human rights today. Capturing a person immediately after an invasive surgery, without prior summons to appear objective - does not fulfill the conditions to imprison. Such a person does not stand at risk to the regularity of the proceedings; moreover - coercive measures or preventive - should be applied adequately to the factual circumstances justifying the fulfillment of the basics of general and specific implementation. Besides, questioning of the then suspect in pain, humiliated (conducting operations when the suspect was flooded with urine) without a prior medical examination, without distributing appropriate medicines and hygiene products - indicates a violation of the rights belonging to every human being, which does not justify in any way the need of implementation of the principle of legality by the authority designated for prosecution. Meanwhile, for the Prosecution Office, despite carrying out the investigation for several months, the next day after the discharge of the patient by the hospital post radical surgery for prostate cancer, seemed the most suitable date for the implementation of actions to stop just the person being investigated, escorting him without a medical examination, as well as a two-day hearing even late at night without adequate medication and medical assistance.

\subsection{Case number II}

Even more extreme case concerned the suspect, who was in custody in one of the major cities in the central part of Poland. From the beginning, just after he was applied the strictest preventive measure, provided by the Polish criminal procedure, he applied for its repeal and change to a milder one, relying primarily on a poor state of his health and inability to take effective treatment in the conditions of detention. The applicant's health, even before placing him in custody, was not in its best. Social Insurance Institution (ZUS) acknowledged his $50 \%$ of bodily injury and permanent invalidity. PSA test results were $30,1 \mathrm{ng} / \mathrm{ml}$, where the standard amount in healthy organism equals from 0 to 4 . It proved, therefore, the existence of malignancies in the body of the accused, specifically prostate cancer, which was obviously connected to the need to undergo orderly and systematic treatment. Each subsequent PSA test indicated the persistence of high levels above average. That is why maintaining proper course of treatment was of upmost importance. Unfortunately, since the applicant had been placed in detention, his health rapidly deteriorated, which was associated with abnormal and even reprehensible conduct of the prison doctors. From the very beginning of his isolation, the applicant struggled with the problems that triggered the deterioration of his physical health, and also mental. 
Such most visible symptom was a significant weight loss; for several months it decreased by more than twenty kilograms. The detainee complained to have major headaches, dizziness while changing position of the body, nausea, noise in the head, blurred vision, sensitivity to light, fatigue vision, sleep disorders, pain in the upper abdomen in the supine position, excessive appetite, numbness of the upper limbs, weakness of his right limbs, chills, sweating, constipation, frequent urination, painful haemorrhoids (often bloody) and feeling pain when urinating. Specialists claimed that taking into consideration the results of his medical tests studies and the data gathered in the applicant's medical records, it his ailments of the urinary tract in the form of chronic prostatitis with the presence of hemorrhoids and discomfort the nervous system in the form of a right-hand paralysis slight degree were of primary concern. These ailments could be treated with the accused being in detention, but "they required further assessment, in particular the reason of significantly elevated PSA values remained unclear, suggesting the presence of the prostate cancer". The applicant had to be provided with anti-inflammatory drugs and the repetition of tests after 3 months. It is obvious, however, that in conditions of isolation, pharmacological treatment is applied with delay, and sometimes with pauses, due to having to wait for the prison doctor. The rules of admission of a prisoner are very complicated.

A detainee must subscribe to the appropriate waiting list because a doctor may appear once every two weeks, and he/she is not always able to meet everyone in need. Moreover, even the possibility of paying visits to the doctor, does not guarantee the stability of the treatment because of having to wait for the implementation of a prescription. In addition, in spite of the recommended at least 3 months of treatment, a discontinuation of using certain drugs happened only after one month, as a consequence of which an obvious deterioration of health of the detainee appeared.

Yet another humiliation for the applicant was the administration of these drugs (some were taken in tablet form, other in the form of suppositories), based on the fact that the drugs were delivered without the original packaging and in a reusable paper envelope. It should also be mentioned that the clinic doctors refused the complainant their help, medical interventions in relation to his tiring continuing health problems, or even administering painkillers. Their refusal was accompanied by snide remarks, especially unpleasant for the applicant's insinuations about simulating symptoms. The applicant's mental state kept deteriorating because of harassment by the employees of the detention center. More than two hundred times the applicant was stripped naked during the inspection, when his urological diseases also were a reason of shame and embarrassment. 


\subsection{Case number III}

Another case of the violation of human rights of the suspect took place in the so-called multiplayer case in which law enforcement tried to get incriminating evidence from the fellow members of the group by any means. Unfortunately, in this case the multiplicity of infringements occurred. And so on the forefront it is primarily a matter of the applicant's health, which deteriorated markedly in the conditions of detention. A serious ailment of the detainee was found; it was related to the rupture of muscle left arm, which took place during the use of physical force during his arrest. This condition required surgical intervention - which was impossible to be performed in. The correctness and professionalism of medical aid was of great significance to the applicant since he had been training competitive sports and the lack of adequate medical care in this area could have lead to irreversible consequences for his medical condition. Medical examinations carried out in two cities of Poland at the request of the applicant were very superficial - not even the necessary research in the form of X-rays was performed. The prosecutor leading the investigation called these ailments "alleged" as evidenced by the fact that both the detainee and his counsel refrained from obtaining information studies from the Department of Criminal which testified to the then state of health of the applicant. The prosecutor's office in response to complaints concerning the deteriorated health of the applicant - emphasized that "...The prison did not inform of any problems". Unfortunately, for a long time the same prosecutor's office did not ask for any medical tests by an expert doctor who could decide in a credible way, what it the actual state of health of the applicant was and in what conditions should the surgery have been performed. Due to such a superficial and unprofessional examination, the applicant feared that surgery in conditions of detention could be just as unprofessional. The use of isolation means and ways of conducting it, violated the applicant's fundamental rights, making the measure inconsistent with the acts of international law, since his test results indicated the need for surgical intervention but he was not allowed to undergo treatment outside the detention center. It should be noted as well that the applicant did not receive appropriate and necessary rehabilitation that he much needed in such a situation. Furthermore, while assessing the current course of research and quality, one cannot fail to notice significant deficiencies in their conduct - even in the form of lack of necessary X-rays in order to make proper diagnosis. The objectives of criminal procedure in Poland should not be achieved at all costs, including risking life and health of the applicant in a situation where it was not possible to keep the applicant in isolation without deteriorating his health state.

In the same case, the violation of Article 8 of the Convention took place as well, that is the breach of the right to respect for family life. Due to incomprehensible reasons Prosecutor's Office did not grant the applicant permission to regular visits of his wife that is, once a month, and also disagreed to a visit of his wife accompanied 
the applicant's six-months-old son. This pressured the applicant no only to give evidence blaming others, but also to deteriorate his own position as the suspect. Prolonged isolation, no contact with the child, triggered the applicant's feeling of depression. He longed for his son, regretted the fact that he would grow up without his father. For the applicant it was very unfair that initially (for over a year), he was not allowed to see him even for a moment, and later very rarely and only through the glass. The applicant after eight years of marriage, managed to conceive a child, and was not permitted to enjoy time with his wife, because national (district) courts in Poland prolonged the use of preventive measure in the form of detention, for a long time. The whole situation was extremely onerous for the applicant, because a little child at this age knows the world, the environment and people only through direct contact (touching, hugging, and talking to it). The child could not imagine or remember the applicant yet. Due to that, the applicant became a stranger to his own son. Every child needs to have his/her needs of safety and positive emotional contact with their loved ones adults met. The situation of tension in the family, the state of uncertainty and the fact that the applicant's wife had to run the house, provide financial security, and take care of the child for several months on her own - all this caused that she found it difficult to meet the important needs and mental development of the child. In this age a feeling of security, positive relations with adults and supporting independent activities conducive helps to develop speech, imagination, memory, learning and other such types of processes. In the post-infant period, a child begins also to learn identifying their gender. They learn by mimicking behavior. The presence of both parents is therefore very important to them. The applicant's child is a boy, and so direct of observation of the father's behavior, performing his various activities, playing together would give the opportunity to learn the functioning adequately to their sex. Unfortunately, the applicant's son was raised in a single-parent family and the complainant feared that a further prolongation of his isolation would have a devastating impact on shaping the personality of his son, the functioning of his social relations and the development of his intellectual performance. The negative impact of the separation between the father and the son could be permanent and could impinge on his life. Lack of normal, real experiences with the members of the immediate environment - could cause problems with unmet development needs in the future. The emotional development motivates a person to behave in a certain way, introducing the body into a state of readiness to cope with different situations, and therefore directly affects cognitive development, as well as health. According to the World Health Organization physical, mental and social development is a standard. Every state diverse from that may be considered a disease. The child's right to be with his father, when he should be respected. It is better to prevent the disease rather than cure it. Summing up, it should be noted that because of the long and drastic restrictions imposed by the Prosecutor's Office and the State Court in Zgierz City on the applicant's personal contact with his wife and child, his right to stay close to family had been violated. 
The prosecution, despite the numerous requests of the applicant and his wife, to give permission for their contacts, for unjustified reasons they were denied them, despite the fact that the applicant's wife was not a person involved in the proceedings. She was neither a co-accused, nor even a witness in the case, so the fear of cheating did not exist. All this clearly contradicts the norms of international law. The Court has repeatedly ruled that the detention, as well as any other measure depriving a person of liberty, entail restrictions on one's private and family life. However, a detainee's right to enable his contacts with should be respected?

In that case, moreover, another violation of the Convention occurred, related to the use of a preventive measure in the form of detention a period longer than justified The complainant in this case repeatedly raised the fact that his arrest was unusually long and, therefore, violated the "reasonable time" guaranteed in article five, paragraph three of the Convention. It states that "everyone arrested or detained in accordance with the provisions of paragraph 1c) of this Article [...] shall be entitled to trial within a reasonable time or to release pending trial. Release may be conditioned by guarantees to appear for trial". The use of a preventive measure in the form of detention is in the light of the Polish criminal procedure the most burdensome means for the accused, but it is not the only preventive measure that can be applied in the light of the provisions. The presumption of a violation of Article 5, paragraph 3 of the Convention in question, therefore, was connected with several refusals to lift the provisions on detention of the applicant. In the opinion of the applicant and his counsel, the application of other means, less burdensome for the applicant, such as social guarantee, granted by the applicant's employer, the acceptance of which the court repeatedly refused would be sufficient to apply for the security purpose of the proceedings. National Court in Zgierz City did not acknowledge the requests of the applicant to use preventive measure in the form of bail, brought by the applicant's lawyer and estimated over the standard salaries of workers in that period. National Court in Zgierz City refused to exempt the preventive measure in the form of detention and the use of it milder terms, claiming the existence of the high probability of the applicant's committing the act that he was suspected to, and also fear that the applicant is likely to induce witnesses to give false testimony and obstruct the proceedings. The court did not mention, however, any specific factual basis in relation to the concerns of collusion, moreover, it did not take into account that the applicant wished to cooperate with law enforcement authorities by submitting explanations in the case, which, despite many pleas, the Prosecutor office refused to accept. They were received only after, and not before the meeting concerning detention, thus preventing the applicant from realization of his rights to defense.

${ }^{7}$ See the sentence in the case Klamecki Against Poland of April 3, 2003, p. 27, § 144, www. coe.org.pl 
In this context, it should be emphasized also that one of the grounds on which the courts in Poland relied on, namely the risk that the applicant would induce witnesses to give false testimony, was not supported by any specific circumstances, but the fact that the applicant pleaded not guilty. This fact should never be held against him, because every suspect in Poland in a criminal trial has the right to the presumption of innocence. It should be also mentioned that high penalty for the offense cannot justify the entire period of detention, mainly because the authorities did not indicate even a single piece of evidence proving that if the applicant had been released, he would have go in hiding or avoid justice. It can be seen, therefore, that justifying the extension of the applicant's detention that national courts in Poland tend to use a repeatable reason, not referring to new facts and circumstances concerning both the complainant and various stages of the proceedings against the person. Deteriorating state of health of the detainee, described above, affected his mental state as well. The deepening depression made staying in the detention center increasingly burdensome and too onerous.

The applicant's family situation also had a significant impact on his mental condition, which has dramatically deteriorated since his arrest. Prolonged stay of the applicant in the detention center led the applicant's wife to search for the help of a psychologist, and this was clearly due to the depression caused by prolonged isolation of her husband. During the applicant's stay in the detention center, she was also forced to ask for the help of others - in order to provide care for their tiny baby during her working hours, which made her the only breadwinner of the whole family.

As a result of the Prosecutor's refusal to let the applicant see his child, the detainee had no contact between the two. The applicant was arrested when the baby was a few months old. From the time of his capture, he had no eye contact with his son for two years - which hurt the psyche of the child and the applicant, and the permits for the vision though the pane it created an additional suffering because of the inability to even hug his son. Using detention as preventive measure was therefore a serious suffering for the detainee that caused family problems.

\section{GUIDELINES OF THE EUROPEAN COURT OF HUMAN RIGHTS}

To sum up, it should be noted that preventive measures should be applied in accordance with the principle of proportionality, minimizing their use to cases essential, necessary and always analyzing the possibility of implementing preventive measures milder than detention. The Court claims the same, in a number of rulings emphasizing that, in accordance with Article 5 paragraph 3 of the Convention, the authorities in deciding whether to maintain or revoke a person's detention are 
obliged to consider the use of alternative security measures ${ }^{8}$. Furthermore, the Court accepts that the suspicion against the applicant of having committed the alleged serious offenses could initially justify the use of his detention, however, does not consider that this condition was appropriate and sufficient to justify the entire period of detention, even if the courts do not comply with health, personal and family situation of the applicant as the current speaker against the use of detention ${ }^{9}$. Due to the abovementioned reasons, the complainant alleged also the violation of the Article 5 paragraph 3 of the Convention, suggesting a too longterm was used as a preventive measure in the form of detention.

Summing up, it is clear that in accordance with Article 3 of the Convention for the Protection of Human Rights and Fundamental Freedoms, the state must ensure that a person arrested or detained in Poland stays in conditions that are consistent with respect for human dignity and to the type and manner of performance of the measure did not give her suffering and toil exceeding the unavoidable level inherent in detention and taking into account of the practical demands of imprisonment, their health and well-being are adequately secured by, among other things: provide the necessary medical care, as reflected in the Court gave a number of rulings. The Court also defines the concept of degrading treatment, stating that an action which "arouses in the victim feelings of fear, suffering, or feelings of inferiority, capable it to humiliate and degrade" and "moreover enough to the feeling of humiliation was a subjective feeling of the victim" can be considered as such ${ }^{10}$.

In the case Hummatov Against Azerbaijan ${ }^{11}$, the Court noted that medical examination and recommendation of specific forms of treatment cannot automatically mean that the medical treatment given to the prisoner was right. The authorities must allow not only a visit of a doctor and conducting medical study, but also creating the conditions for the effective application of the assigned treatment. The Court held that the situation, in which providing essential medicines - for serious diseases drugs can be expensive - requires financial support of the family, means that the overall quality of medical care in prison does not correspond to the requirements of article 3. States must systematically control the health and living conditions of prisoners, taking into account the normal and reasonable requirements of imprisonment. An important protection against any form of abuse of detainees is a proper medical examination. It must, however, be carried out in the absence of a police officer and by a properly trained and equipped with

${ }^{8}$ See the judgment in the case Itowiecki Against Poland, October 4, 2001, p. 14, §63, www.coe.org.pl

${ }^{9}$ See the judgment, p. $14, \S 62$, see the judgement in the case Klamecki Against Poland, April 3, 2003, p. 21, §122, www.coe.org.pl

${ }^{10}$ See the judgment in the case Iwańczuk Against Poland, November 15, 2001, p. 10, § 51, www.coe.org.pl

${ }^{11}$ See the judgment in the case Hummatov Against Azerbaijan, November 29, 2007, The Chamber (Section I), Complaints No 9852/03 and 13413/04, §116 and 117. 
broad powers physician. A medical opinion given after the test, which took place in the presence and under the supervision of persons who commit a breach of the provisions of the Convention, cannot be considered credible. In the event of negligence by the state of such activities it is not exposed to a legitimate complaint alleging infringement of the third article of the Convention. This undoubtedly happened in the cases mentioned above, when the authorities did not do anything substantial to improve the health of prisoners and provide them with adequate medical care, and also did not show proper respect towards people who were still subject to a presumption of innocence.

In the case Iwańczuk Against Poland, the Court noted that the detainee, whose criminal responsibility was not confirmed by a final judgment, is to use the presumption of innocence.

It does not apply only to the procedural rights related to criminal proceedings, but also to the legal regime defining one's rights while in custody, including the method of treatment by the prison administration. It remains under the full supervision of the authorities, and therefore the treatment - due to its weaker position - must be subjected to strict controls under the Convention. The state has a duty - regardless of possible logistic and financial problems - to organize its penitentiary system in such a way that the arrestee's dignity is respected. In conclusion, keeping people in custody, ignoring the fact that it could endanger their life or health, without adequate medical care, is an act against Article 3 of the Convention.

\section{CONCLUSION}

These considerations give grounds to a claim that despite multiple attempts (including legal solutions, as well as increased control of international organizations), human rights are still being violated nowadays in Poland during the preparatory proceedings. The examples of such acts do not have to be looked for abroad, in the countries with a shorter tradition of independence, but unfortunately we can find them in preliminary proceedings in criminal cases conducted in Poland (examples presented above). It would seem that in the $21^{\text {st }}$ century, after so many years of functioning in the Polish legal system, the principles of due state and law, such violations would be difficult to trace. Meanwhile, all of the above cases have occurred over the past ten years. What is worse, these are not all the cases in which there appeared violations of human rights, which is often resisted effectively in connection with the practice of the profession. No one will ever hear about many of them. And even those who challenged to the European Court - have led to a final finding of infringement of the rights of our country, they do not give foundations to the conclusion that they become a warning to continued violations of human rights in Poland in the course of preparatory proceedings. The bodies established 
to prosecute crimes, despite decisions to the applicants and compensation granted to them, continue to commit these violations, regardless of the consequences. The achievement of the objectives of the criminal proceedings, and sometimes the goals personally chosen because of the perspective of promotion or recognition of one's superiors - like in these above mentioned cases, are becoming the reason of such a practice. Unfortunately, even the judgment issued by the Court, confirming the validity of the complaint and often paid post factum compensation are not able to compensate the applicant for what they survived. Physical or mental suffering does not go without leaving an imprint in the man's psyche and no financial compensation can make up for the wrongs he suffered made in the alleged "law". Happily, our state still provide amendments, which introduce in polish criminal trial new standards in pre-trial detention. Nevertheless, our polish regulation still needs new provisions, which could adequate supervision during the preparatory proceeding guaranteed.

\title{
BIBLIOGRAPHY
}

Nowicki, Marek A. 2013. Wokót Konwencji Europejskiej. Komentarz do Europejskiej Konwencji Praw Człowieka. Komentarz. LEX.

\section{Legal acts}

The Convention for the Protection of Human Rights and Fundamental Freedoms drafted in Rome on November 4, 1950. Dz. U. 1993, No 90, p. 587.

Protocol No 1 and No 4. Dz. U. 1995, No 36, p. 175/1 - binding act.

Protocol No 2. Dz. U. 1995, No 36, p. 176 - archival act.

\section{Jurisdiction}

An Action Against Turkey. No. 40145/98 - sentence from 2005.

Complaint v. Spain. No. 51192/99 - decision of 2001.

Chember Against Russia of July 3, 2008. Chamber (Section I), application No. 7188/03, § 50.

Iłowiecki Against Poland of October 4, 2001. P. 14, § 62 and 63, www.coe.org.pl

Klamecki Against Poland of April 3, 2003. P. 21, § 122 and p. 27, 144.

\author{
Katarzyna Rydz-Sybilak
}

\section{LAMANIE PRAW CZLOWIEKA NA PRZYKLADACH AKTUALNEJ PRAKTYKI ADWOKACKIEJ W KILKU SPRAWACH KARNYCH}

Streszczenie. Zagadnienia związane z ochroną przed torturami lub innym nieludzkim czy poniżającym traktowaniem uregulowane są w systemie europejskim nie tylko w Europejskiej Konwencji Praw Człowieka, ale również w Europejskiej Konwencji Przeciw Torturom, którą Komitet Ministrów Rady Europy przyjął 26 czerwca 1987 r., ratyfikowanej obecnie przez wszystkie 47 państw Rady Europy. Jest ona ważnym uzupełnieniem przede wszystkim w zakresie mechanizmu kontroli. Uznano, że system ochrony oparty na skargach indywidualnych i skargach między 
państwami należy wzmocnić środkami o charakterze prewencyjnym. Wiele sytuacji, w których na państwie ciążą poważne obowiązki, aby nie doszło do naruszenia art. 3 Konwencji, ma miejsce w związku z postępowaniem karnym prowadzonym przez organy uprawnione do realizowania zasady legalizmu. W tym miejscu podnieść niestety należy, iż pomimo ratyfikowania przez nasz kraj powyżej wskazanych aktów prawnych, właśnie w trakcie prowadzonych postępowań przygotowawczych w sprawach karnych najczęściej dochodzi do naruszeń praw człowieka w kontekście nakazu godnego i humanitarnego traktowania osób podejrzanych, czy już oskarżonych. Państwo musi zapewnić, aby postępowania te odbywały się w warunkach wskazujących na poszanowanie ludzkiej godności, a procedury i metody pozyskiwania dowodów obciążających podejrzanych nie powodowały u świadków czy też podejrzanych udręki lub cierpienia, których skala i intensywność przekraczałyby potrzeby procesowe osobistego zabezpieczenia osoby podejrzanego dla celów postępowania karnego, przy zachowaniu wymogów procedury karnej dotyczącej zatrzymania oraz stosowania środka zapobiegawczego w postaci tymczasowego aresztowania.

Słowa kluczowe: prawa człowieka, ochrona praw człowieka i podstawowych wolności, zakaz tortur i niehumanitarnego traktowania, tymczasowe aresztowanie, dowody obciążające, prawo do obrony, skarga do Europejskiego Trybunału Praw Człowieka. 